\title{
Slab detachment of subducted Indo-Australian plate beneath Sunda arc, Indonesia
}

\author{
Bhaskar Kundu* and V K Gahalaut \\ National Geophysical Research Institute, Council of Scientific and Industrial Research, \\ Uppal Road, Hyderabad 500 00\%, India. \\ *e-mail: rilbhaskar@gmail.com
}

Necking, tearing, slab detachment and subsequently slab loss complicate the subduction zone processes and slab architecture. Based on evidences which include patterns of seismicity, seismic tomography and geochemistry of arc volcanoes, we have identified a horizontal slab tear in the subducted Indo-Australian slab beneath the Sunda arc. It strongly reflects on trench migration, and causes along-strike variations in vertical motion and geochemically distinct subduction-related arc magmatism. We also propose a model for the geodynamic evolution of slab detachment.

\section{Introduction}

Subduction of oceanic lithosphere plays a vital role in plate tectonics, thermal evolution of the mantle, and recycling process between earth interior and surface (Tatsumi 2005). Thus Earth's subduction zones are probably the best windows to look into the Earth's interior. Seismic images (Koper et al 1999), geochemistry of arc volcanoes (McCulloch and Gamble 1991; Hofman 1997) and numerous geodynamic models (Kincaid and Olson 1987; Davies and Stevenson 1992; Stegman et al 2006; Schellart et al 2007) have improved our understanding significantly about the subduction zone process. However, necking, tearing and subsequent break-off of subducting slabs make slab architecture much more complex, which are well documented worldwide using geophysical observations (e.g., Barazangi et al 1973; Protti et al 1994; Gvirtzman and Nur 1999; Wortel and Spakman 2000; Bautista et al 2001; Levin et al 2002; Ferrari 2004; Miller et al 2006; Richards et al 2007; Rosenbaum et al 2008; Lister et al 2008; Obayashi et al 2009; Schellart et al 2009; Kundu and Gahalaut 2010). Slab tearing produces physical gaps in subducted slabs that enhances asthenospheric inflow around the lateral edges of the tear (Kincaid and Griffiths 2003; Schellart 2004, 2008; Stegman et al 2006) and reflects on geochemistry of subduction-related arc magmatism (Maury et al 2000; Yogodzinski et al 2001; Guivel et al 2006). In case of sub-horizontal slab tear, it can affect the seismicity by creating gaps in seismic clusters, and may lead to a slowdown in subduction velocity because of the sudden loss of slab pull force at the detached segment of the subduction zone. This may further enhance the trench retreat at segments where the slab is continuous (Wortel and Spakman 2000). However, in case of sub-vertical tearing (e.g., southern Mariana arc, Miller et al 2006), there is no such loss of slab pull forces and trench retreat processes are observed for both of the subducted segments because of more efficient toroidal-type return flow (Schellart et al 2007).

We investigate the northward subduction of the Indo-Australian plate along the eastern Sunda arc right from northwestern Sumatra, along Java to

Keywords. Slab detachment; subduction zone; Sunda arc; Indo-Australian slab; trench migration. 


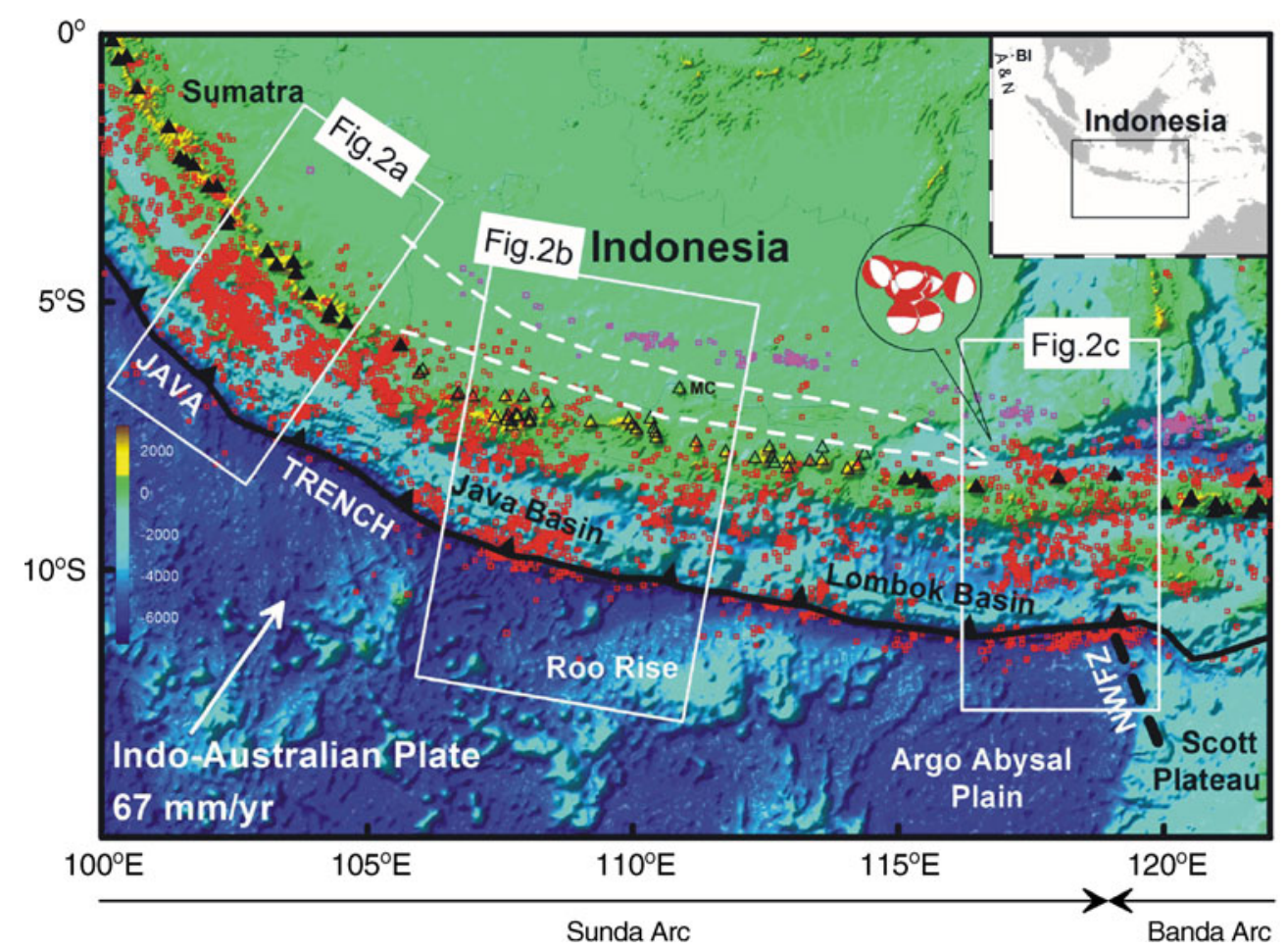

Figure 1. Map of the eastern Sunda arc, Indonesia, with major tectonic and bathymetric features of the region with earthquakes of $\mathrm{M} \geq 4.0$ from EHB catalogue (Engdahl et al 1998). Deeper seismicity ( $>450 \mathrm{~km}$ ) is represented by pink colour, whereas shallow and intermediate seismicity $(<450 \mathrm{~km})$ is shown by red colour. From these earthquakes a wedgeshaped seismic gap along the strike of the slab from $105^{\circ} \mathrm{E}$ to $115^{\circ} \mathrm{E}$ may be noted (shown with dashed lines). Near the tip of the seismic gap, focal mechanisms of an earthquake cluster imply tensile motion. Triangles represent arc volcanoes. Volcanoes in Java arc are shown by open triangles and the largest along-strike variation at volcanic front is noted here. Earthquakes in three rectangles across the trench were used for preparing cross sections in figure 2. Arrow indicates IndoAustralian plate movement at the rate of $67 \mathrm{~mm} / \mathrm{yr}$. NWFZ: North Wilson Fracture Zone; MC: Muriah complex; A \& N: Andaman and Nicobar Islands; BI: Barren Island (shown by a triangle in the inset).

Flores (figure 1), with the aim of understanding and developing a geodynamic model for the region. This region appears distinct from other arc blocks (Andaman or northern Sumatra) of the Sunda arc-trench system in many respects. Firstly, the largest along-strike variation has taken place at the volcanic front in the Java arc block and as a result it shows overlapping ends of two volcanic lines in this region (Syracuse and Abers 2006). Secondly, geochemical signature of arc magmas is enigmatic (Whitford et al 1979; Foden and Varne 1980; Nicholls and Whitford 1983; Syracuse and Abers 2006). Thirdly, a pronounced seismic gap in between earthquake focal depths of $300 \mathrm{~km}$ and $500 \mathrm{~km}$ is evident in the Java arc block and interestingly some of the High-K Calc-Alkaline and High-K Alkaline Quaternary to recent volcanoes (Foden and Varne 1980; Nicholls and Whitford 1983) are seated above that seismic gap. Fourthly, an abnormal increase in thermal parameter, $\Phi(\Phi$ is defined as the product of vertical subduction velocity, $V_{V}$ and the age of the lithosphere at the trench, $\left.t_{\text {Age }}\right)$ from $4 \times 10^{3} \mathrm{~km}$ west of $105^{\circ} \mathrm{E}$ to $5.6 \times 10^{3} \mathrm{~km}$, east of $105^{\circ} \mathrm{E}$ is also reported in the region (Kirby et al 1996). Considering the abovementioned inherent complexities, developing a suitable geodynamic model for this region is a quite challenging task. But before that we provide a brief review of regional tectonics of the eastern Sunda arc.

\section{Tectonics of eastern Sunda arc}

The orientation of $5200 \mathrm{~km}$ long diverse Sunda arctrench system (Schellart et al 2007, table 1) gradually changes from east-west along Java to northsouth along the Sumatra and Andaman Nicobar Islands (figure 1). As a result, the relative plate motion between the subducting Indo-Australian plate and the overriding Sunda plate is nearly arc normal in the eastern end of the arc with no slip partitioning. However, at the western end, highly oblique plate motion is partitioned into thrust and strike-slip movement in the front and back-arc region (Fitch 1972; McCaffrey 1992; Curray 2005). The rate of subduction of the Australian plate decreases gradually from $76 \mathrm{~mm} / \mathrm{yr}$ at the eastern 
end to $60 \mathrm{~mm} / \mathrm{yr}$ at the western end of Sumatra coast (Müller et al 2008). Australian continental lithosphere has been colliding with the western Banda arc since about 9-10 Ma (Keep and Haig 2010), along the islands of Flores, Sumba, and Timor (Hall 1997). The subduction process of central Java is dominated by the collision of the oceanic Roo Rise (rough and high relief reaching height of about $2.0-2.5 \mathrm{~km}$ above the general level of the surrounding ocean floor) with the fore-arc between $109^{\circ} \mathrm{E}$ and $115^{\circ} \mathrm{E}$, while the Argo Abyssal Plane (smooth and about $1500 \mathrm{~m}$ deep below sea level) interacts with the fore-arc of Lombok and Sumbawa between longitudes $115^{\circ} \mathrm{E}$ and $119^{\circ} \mathrm{E}$ (figure 1). Such topographic variations along the trench modify the Sunda arc curvature (Kopp et al 2006, figure 1). Apart from that, magnetic seafloor-spreading anomalies depict that the age of the subducting ocean floor varies from 50-90 Ma along Sumatra to 100-135 Ma and 140-160 Ma near Java and Flores, respectively (Sdrolias and Müller 2006). Thus lateral variation of the nature and age of the subducting IndoAustralian plate influences the style of deformation and seismicity along the Sunda arc (Widiyantoro and van der Hilst 1996).

\section{Evidences for slab detachment}

\subsection{Seismicity}

Evidence for slab tearing beneath central Sunda (Java) comes primarily from earthquake data. We use an updated catalogue of EHB seismicity (Engdahl et al 1998) and plot hypocenters of earthquakes between 1960 and 2008 in figure 1. Figure 2 shows depth section across the regions, marked in figure 1 by rectangles. Earthquakes with focal depths of around $670 \mathrm{~km}$ occur in the steeply dipping $\left(\sim 60^{\circ}\right)$ seismic zone beneath the Java arc, but there is a distinct gap in seismicity between depths of 300 and $500 \mathrm{~km}$ (Isacks and Molnar 1971). The clearly defined wedge shaped seismic gap and its sharpness along the strike of the slab (from $105^{\circ} \mathrm{E}$ to $116^{\circ} \mathrm{E}$ ), suggest that such gap may be real (figure 1). Such characteristic seismic gap may be explained in two ways. Firstly, in this depth
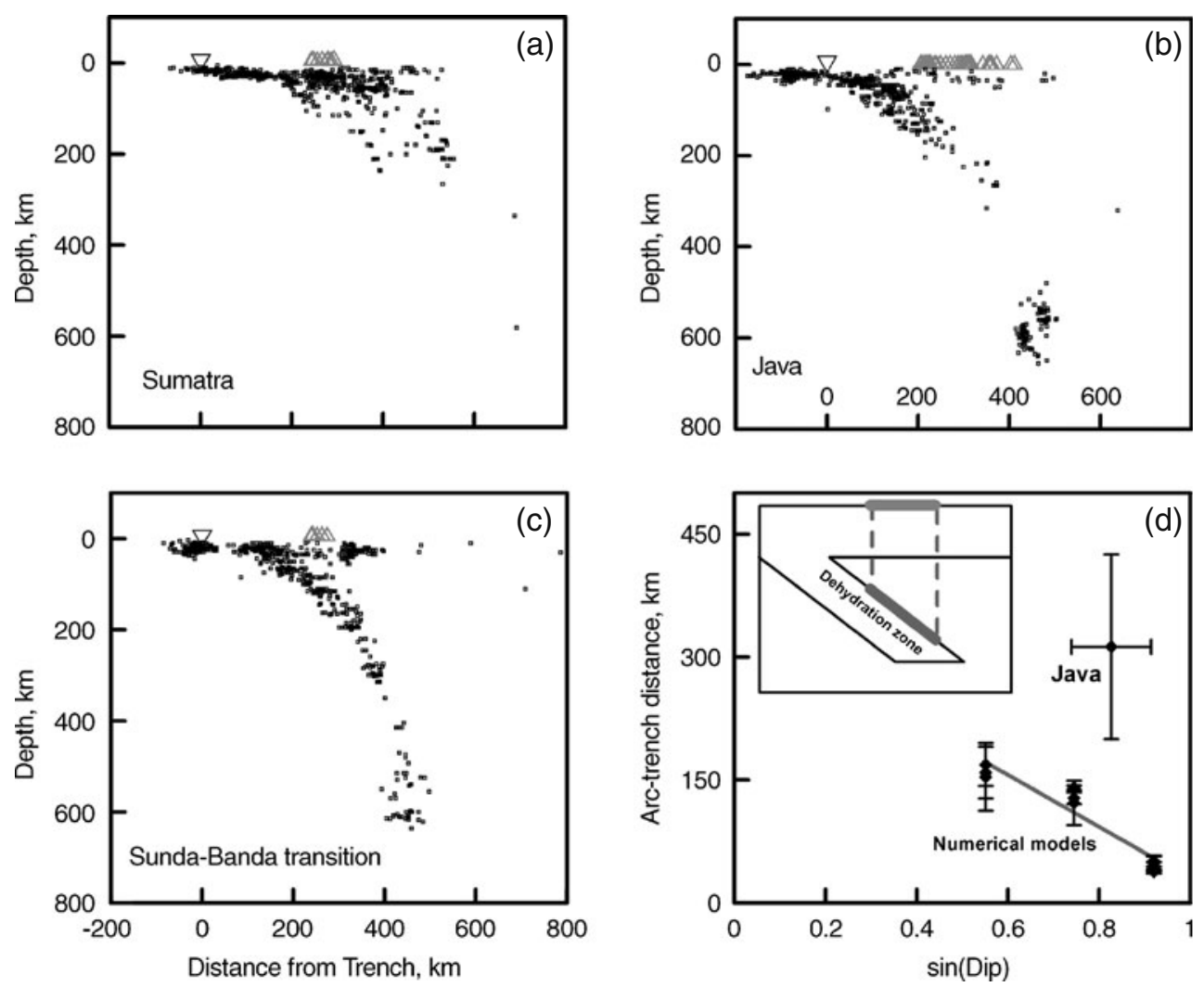

Figure 2. Cross sections of EHB (Engdahl et al 1998) seismicity in three regions (panels a, b and c) across the trench. Black and grey triangles represent position of the trench and volcanoes, respectively. (b) Distinct seismic gap at depth 300-500 km may be noted beneath Java arc. A few high-K alkaline arc volcanoes are located just above the seismic gap. (d) Variation of arc-trench distance with dip of the subducted slab. The range (shown by vertical error bar) indicates the width of the volcanic arc. Java arc shows significant deviation from linear correlation between slab dip vs. volcanic arc width and arc-trench distance (Grove et al 2009). Inset in the panel defines the width of the volcanic arc. 
interval, there is a switch over from down-dip extension at shallow depth to down-dip compression at greater depth of the slab, as can be seen from gentle plunge of $\mathrm{T}$, and steep plunge of $\mathrm{P}$ axes of focal mechanisms of earthquakes at greater depth (figure 3). To further emphasise this, we inverted these focal mechanisms of earthquakes (Michael 1987) with shallow, intermediate and deep depth. It can be seen that the direction of maximum principal stress, $\sigma_{1}$, changes from steep at shallow depth to very gentle at intermediate depth and almost vertical at deeper depth levels, again highlighting the change from down-dip extension at shallow depth to down-dip compression at greater depth. Thus this may be the zone of low differential stress (Isacks and Molnar 1971). Secondly, lower part of the slab is detached by a horizontal tear which propagated in eastward direction, creating a physical lithospheric gap in the slab. Beneath the Sumatra arc, the seismic zone dips at an angle of about $30^{\circ}-45^{\circ}$, but there are no earthquakes at depth deeper than $300 \mathrm{~km}$, which is probably due to the relatively young age of subducted lithosphere (Kirby et al 1996). However, in the eastern Sunda-Banda transition (between Flores and Java), the seismic zone dips steeply $\left(65^{\circ}-70^{\circ}\right)$, but a pronounce slab necking is observed at a depth of 350-450 km. Occurrence of normal focal mechanism type earthquakes with nodal plane predominantly in east-west direction near the tip of the wedge-shaped seismic gap (figure 1) may also indicate slab-tearing in the region. Based on finite-element modelling, Grove et al (2009) proposed that slab dip has a first-order effect on the total width of melting region and shallower slabs lead to wider melting region, suggesting a correlation between slab dip and volcanic arc width and arc-trench distance. But the Java slab shows significant deviation from that trend (figure $2 \mathrm{~d}$ ) as it shows relatively larger width and greater distance from the trench.

\subsection{Tomographic study}

Apart from seismicity, morphology of the subducted Indo-Australian slab beneath the eastern
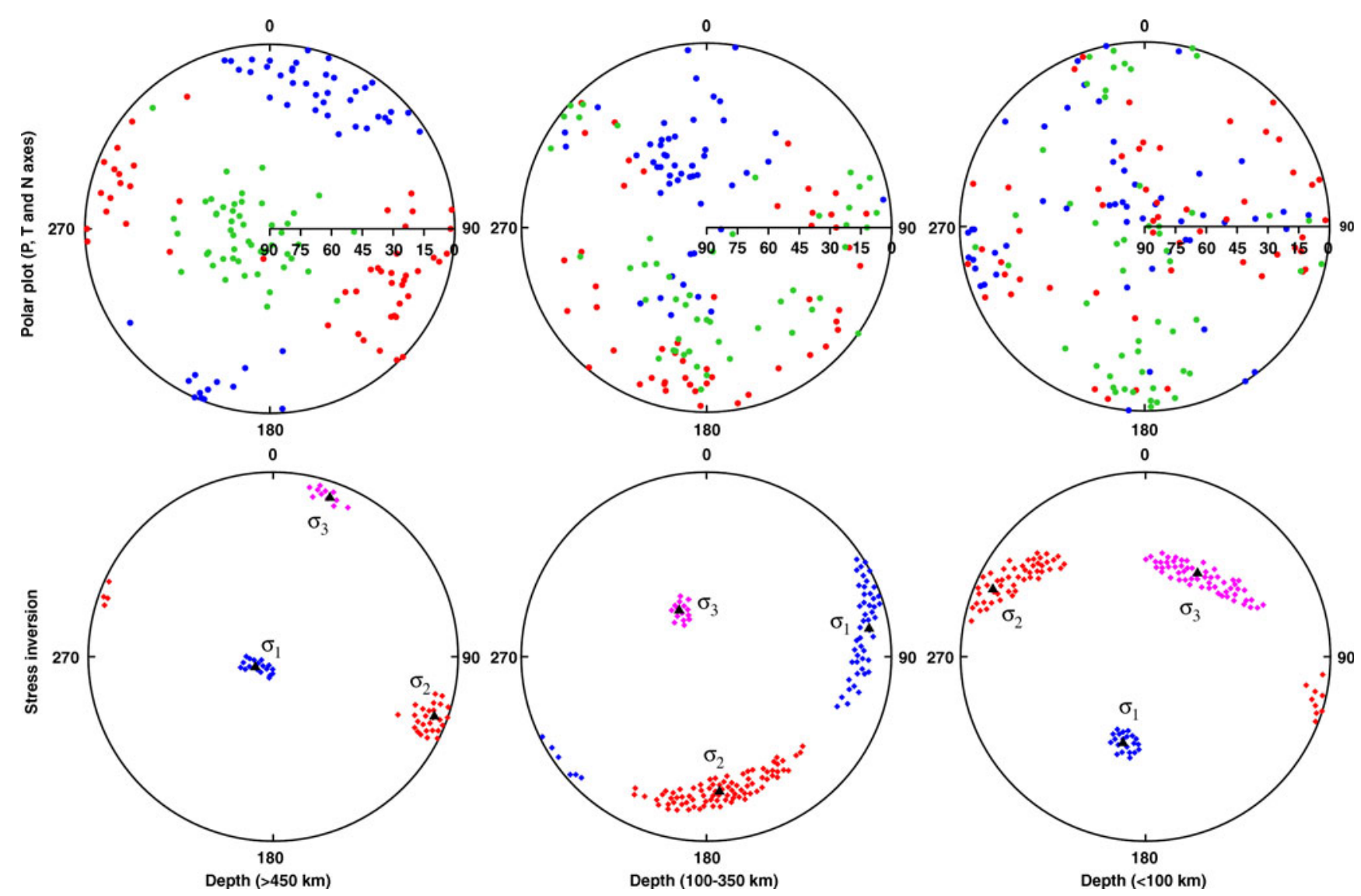

Figure 3. Polar plots of the P, T and N axes from CMT catalogue of earthquakes at different depth ranges of the subducted slab beneath Java arc. P, T and $\mathrm{N}$ axes are represented by green, blue and red dots, respectively. Radius of the circle and peripheral position indicate plunge and azimuth of the earthquakes' $\mathrm{P}, \mathrm{T}$ and $\mathrm{N}$ axes respectively. At greater depth $(>450 \mathrm{~km}), \mathrm{T}$ axis plunge is relatively low but $\mathrm{P}$ axis plunge is higher, which can be explained by the effect of slab resistance force $\left(\mathrm{F}_{\mathrm{sr}}\right)$ acting against the slab pull force $\left(\mathrm{F}_{\mathrm{sp}}\right)$ at $670 \mathrm{~km}$ discontinuity. The lower three panels show the results of stress inversion at deeper, intermediate and shallow depths. The change in plunge and trend in $\sigma_{1}$ may be noted. 
Sunda arc has been well imaged using seismic tomography (Widiyantoro and van der Hilst 1996; Richards et al 2007; Pesicek et al 2008). The subducted slab is defined by a laterally continuous region of higher than average $\mathrm{P}$-wave velocity in the upper mantle $(110-160 \mathrm{~km})$, transition zone $(490-570 \mathrm{~km})$ and lower mantle $(1130-1250 \mathrm{~km})$. It appears that in the upper mantle, higher Pwave velocity strength is parallel to the presentday Sunda arc and in the mantle transition zone, high-velocity slab exists only beneath the Java and Banda arcs, leaving a gap beneath Sumatra. The Java slab is probably continuous and the seismic gap (at 300-500 km) can be explained by thinning or necking of the slab. If this explanation is appropriate, then in the slab necking zone we may expect a tight cluster of earthquake hypocentres, which is generally absent (Lister et al 2008).

\subsection{Geochemistry of arc volcanoes}

We acknowledge that the genetic link between the regional geodynamics and geochemical fingerprints on the depth of melting and the extent of mantle metasomatism is not very straightforward. Using the available data, we investigate and characterize geochemistry of these Quaternary to recent active volcanoes (Whitford et al 1979; Foden and Varne 1980; Nicholls and Whitford 1983) and compare them with the Barren Island volcanic lava geochemistry (Luhr and Haldar 2006), which is located at the east of Andaman Islands. It has been recognised that there is a sharp abnormal increase in the ratio of potassium to silica $(\mathrm{K})$ with depth of slab dehydration $(\mathrm{h})$ at $108^{\circ} \mathrm{E}$ longitude and there is a pronounced decrease in both $\mathrm{K}$ and $\mathrm{h}$ in the western Banda Sea (Nicholls and Whitford 1983). Interestingly, $\mathrm{H}$-series lavas of the Muriah complex (marked by $\mathrm{MC}$ in figure 1) follow the $\mathrm{K}-\mathrm{h}$ trend, while the A-series has a $\mathrm{K}$ value exceptionally far above the extrapolated trend (Foden and Varne 1980).

Some elemental abundances and ratios like LILE/ HFSE and isotopic signature $\left({ }^{87} \mathrm{Sr} /{ }^{86} \mathrm{Sr}\right)$ depend on the nature and intensity of metasomatism and
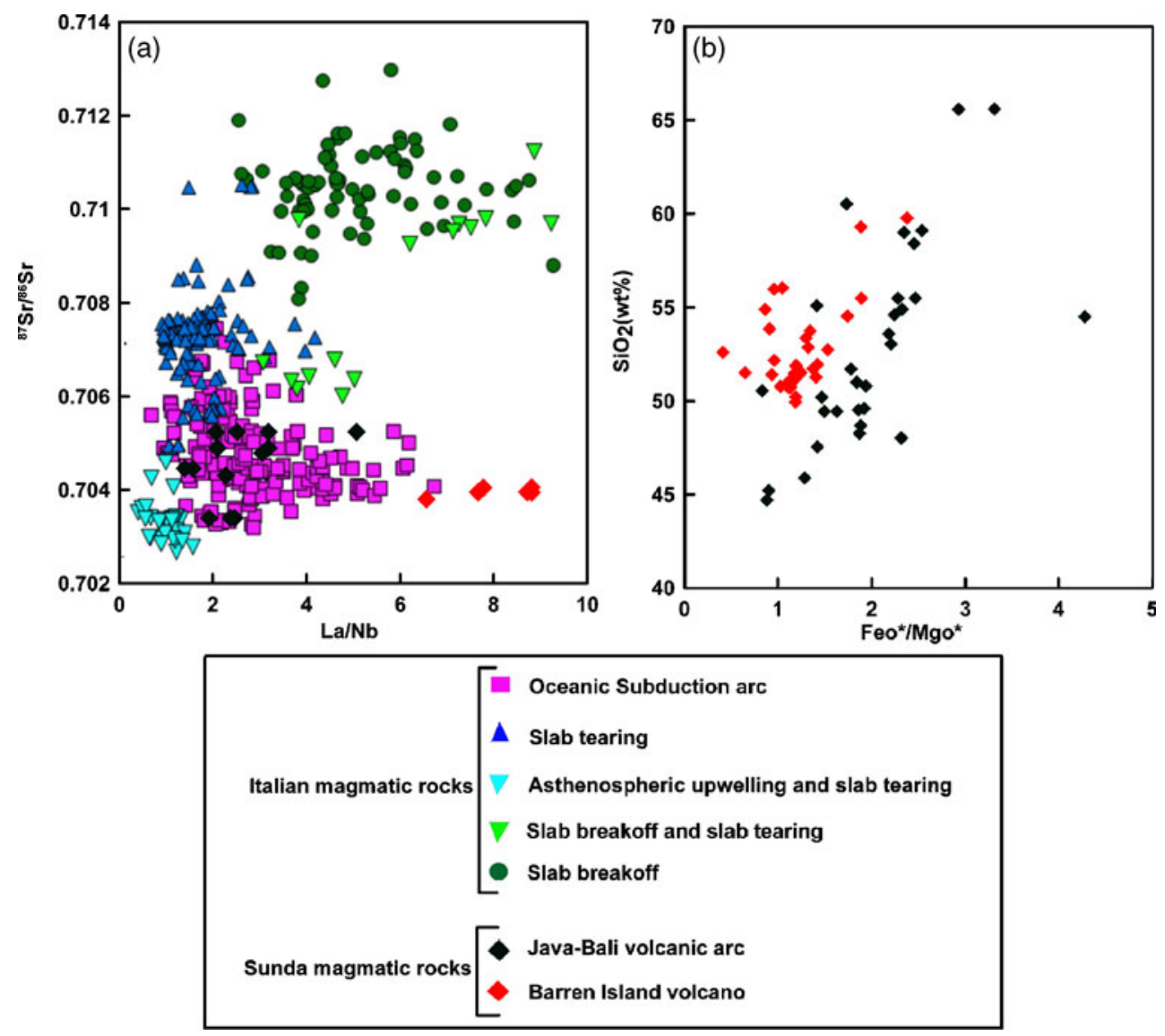

Figure 4. (a) La/Nb vs. ${ }^{87} \mathrm{Sr} /{ }^{86} \mathrm{Sr}$ values for the Quaternary to recent Sunda magmatic rocks in comparison with Italian magmatic rocks (Rosenbaum et al 2008). It is noted that Java-Bali magmatic rocks (Whitford et al 1979; Foden and Varne 1980; Nicholls and Whitford 1983) are very much correlated with oceanic subduction arc related young magmatic rocks from Italian region. Barren Island magma distinctly shows very high $\mathrm{La} / \mathrm{Nb}$ values. (b) Whole-rock $\mathrm{SiO}_{2}$ content vs. FeO*/ $\mathrm{MgO}^{*}$ ratio in Sunda magmatic rocks (Whitford et al 1979; Foden and Varne 1980; Nicholls and Whitford 1983). The primitive andesites have high $\mathrm{SiO}_{2}$ relative to $\mathrm{FeO} / \mathrm{MgO}^{*}$ ratio. 
other compositional features. La/Nb versus radiogenic ${ }^{87} \mathrm{Sr} /{ }^{86} \mathrm{Sr}$ plots are the most convincing evidence for this. Rosenbaum et al (2008) proposed correlations between the development of tear and occurrence of regional magmatic activity with transitional geochemical signatures between arc type and OIB type, which are related to slab tearing and slab break-off for Italian magmatism. Although the
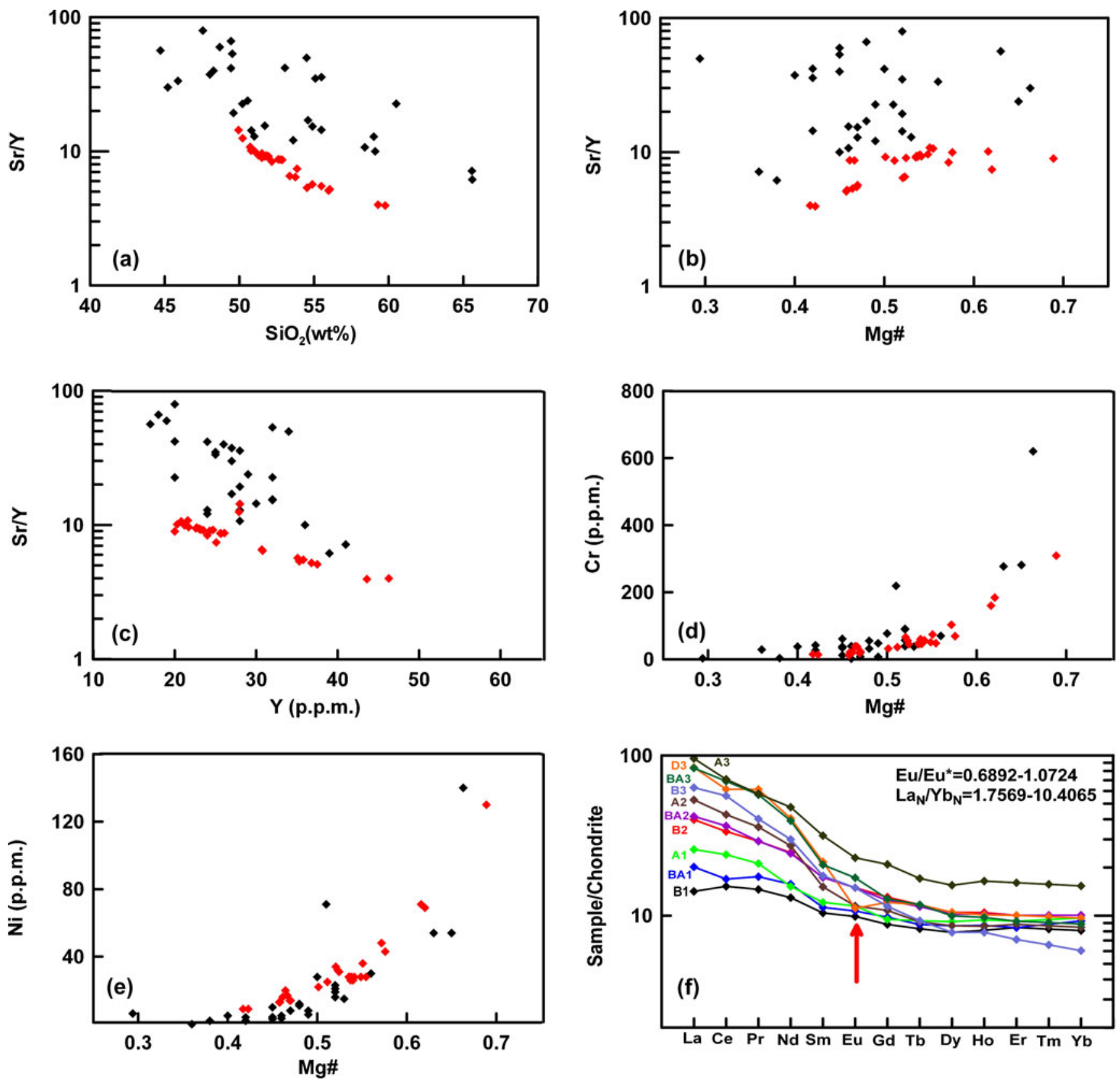

Figure 5. Sr/Y ratios vs. $\mathrm{SiO}_{2}$ content, $\mathrm{Mg} \#$ and $\mathrm{Y}$ content in (a), (b), and (c); $\mathrm{Mg} \#$ vs. Cr and $\mathrm{Ni}$ content in (d) and (e); and REE pattern for volcanic rocks from eastern Sunda arc in (f) (Whitford et al 1979; Foden and Varne 1980; Nicholls and Whitford 1983). Symbols are same as in figure 4(b); $\mathrm{Mg} \#$ (which equals to $100[\mathrm{Mg} /(\mathrm{Mg}+\mathrm{Fe})]$ ) is calculated on a molar basis using total Fe content. The distinctive aspect of the dataset from Java-Bali volcanic rocks is the common occurrence of low $\mathrm{Y}(<25 \mathrm{ppm})$ with high $\mathrm{Sr} / \mathrm{Y}(>25)$, especially in the samples with relatively high $\mathrm{Mg} \#$ and high $\mathrm{SiO}_{2}$. Assimilationfractional crystallization (AFC) or a crystal fractionation of this trend is unusual, the effects of fractionation are clear in the Barren volcanic lava and Java-Bali volcanic rocks, which show strong trends towards decreasing $\mathrm{Sr} / \mathrm{Y}$ with increasing $\mathrm{SiO}_{2}$ (a), decreasing Mg\# (b), and increasing Y (c). Mg\# shows compatible relationship with Cr and Ni content in panel (d) and (e). (f) Anomalously steep REE pattern with small positive to negative europium anomaly $(\mathrm{Eu} / \mathrm{Eu} *=0.6892-1.0724)$ and steep REE patterns ( $\left.\mathrm{La}_{\mathrm{N}} / \mathrm{Yb}_{\mathrm{N}}=1.7569-10.4065\right)$ indicate deeper mantle source for magma generation. Position of europium anomaly is indicated by red arrow. B: basalt; BA: basaltic-andesite; A: andesite; D: dacite, and corresponding number, 1 for tholeiitic series, 2 for calc-alkaline series, and 3 for high-K calc-alkaline series (i.e., BA1 means basaltic-andesite of tholeiitic series magma). 
tectonic setting and the geometry of tear are quite different, in the absence of any other available comparison, we followed the methods adopted by Rosenbaum et al (2008). We found relatively low $\mathrm{La} / \mathrm{Nb}$ and ${ }^{87} \mathrm{Sr} /{ }^{86} \mathrm{Sr}$ values for a few Quaternary to recent active volcanoes for the eastern Sunda arc. It suggests that such mafic magmas are related to a mantle source, probably asthenosphere, and suffered lesser degree of subduction-related mantle metasomatism. Interestingly, Java-Bali samples are very much correlated with the oceanic subduction arc related magmatic rock samples of Italian region, rather than the samples of slab tearing or asthenospheric upwelling related magmatic rocks (figure 4a). Thus one may argue that Java-Bali volcanics can be explained entirely as normal arc volcanics without incorporating slab tearing or detachment, but our further geochemical analyses (presented in figures $4 \mathrm{~b}$ and 5) confirm asthenospheric upwelling, slab tearing and subsequent slab edge melting related abnormal magmatism. Figure 4(b) shows that volcanic rocks of our concerned area are significantly rich in $\mathrm{Mg}$ (lower $\left.\mathrm{FeO}^{*} / \mathrm{MgO}^{*}\right)$ at a given $\mathrm{SiO}_{2}$ content. Thus it is clear that most of the arc volcanoes are displaying highly mafic characters.

We also found anomalously steep rare-earthelement (REE) patterns, high Sr contents and high $\mathrm{Sr} / \mathrm{Y}$ ratios in the andesite to dacite rocks of Quaternary to recent active volcanic rocks of eastern Sunda arc (figure 5). They are also rich in compatible elements like $\mathrm{Cr}$ and $\mathrm{Ni}$. This type of signature is generally recognised in volcanic arcs, where the edge of the plate is exposed to shearing and mantle flow, a situation which is likely to cause these edges to be abnormally hot and physically ablated by the mantle inflow (Yogodzinski et al 2001). As a result, the effects of slab edge melting must be reflected on geochemical behaviour of arc magmas. We suggest that geochemically distinct type of arc volcanoes of the eastern Sunda arc can only be explained in normal subduction scenario if we accept slab detachment beneath the arc. Thus geochemically distinct arc volcanoes appear to be the indicators for the spatial extent of slab detachment.

\section{Evolution of slab detachment process}

\subsection{Propagation of slab detachment}

Wortel and Spakman (2000) analysed dynamic implications of slab detachment of MediterraneanCarpathian region. Using three dimensional finite element modelling, Yoshioka and Wortel (1995) proposed spatio-temporal variations in the state of stress within the slab, as a function of tear length, rheology, and a variety of force distributions. Such state of stress provides high shear stress concentration, of the order of several hundred $\mathrm{MPa}$, which forms near the tip of the tear inside the slab, and is sufficient to cause lateral migration of the tear. One way to test the lateral propagation of slab detachment is to look at the behaviour of the subducting Indo-Australian slab through different time windows.

Slowdown in subduction velocity is caused by gradual loss of slab pull forces immediately after the slab detachment. The concentration of slab pull forces causes the pattern of subsidence and uplift, migrating along the strike of the trench, which also facilitates trench migration (Wortel and Spakman 2000). Using mathematical formulations of slab pull force, ridge push force and slab resistance force in a subduction zone, Carlson et al (1983) showed a good non-linear correlation between the rate of absolute plate motion and the age of lithosphere at trench. Interestingly, West Java fits well in such a non-linear relationship, but East Java deviates from it, probably because of the interaction of relatively buoyant adjacent Australian continental landmass (Carlson et al 1983). We suggest that slowdown in the rate of absolute plate motion in the East Java is because of loss of slab pull forces by gradual slab detachment process with time. To test our hypothesis we construct the same nonlinear relationship in two time windows, at 10 and $20 \mathrm{Ma}$ using data from 12 trenches (figure 6) (Sdrolias and Müller 2006). From this construction we find that at 20 Ma time window, the East Java fits with the trend but not at $10 \mathrm{Ma}$ and $0 \mathrm{Ma}$ time windows. However, the West Java shows slightly higher rate of absolute plate motion at $20 \mathrm{Ma}$ time window and slightly deviates from the trend. We suggest that this discrepancy may be because of the locus of maximum slab pull force concentration that operated beneath West Java during that time window. But at the $20 \mathrm{Ma}$ time window, slab detachment did not extend up to East Java (figure 6d). However, the cause of deviation for both the Middle-America and Peru-Chile trench at $10 \mathrm{Ma}$ and $20 \mathrm{Ma}$ time windows are unknown (figure 6). Recently an alternative view has been put forward according to which (Schellart et al 2010) global dataset of current subduction kinematics indicates negligible-to-moderate correlation between subducting plate velocity and plate age. In contrast, both global dataset and the dynamic models show that average trench-normal subducting plate velocities and trench velocities vary nonlinearly with slab width (W) and have strong correlation. Subducting plate velocity scales with $\mathrm{W}^{2 / 3}$, whereas trench velocity scales with $\mathrm{W}^{-1}$. These findings can be accepted as an alternative 


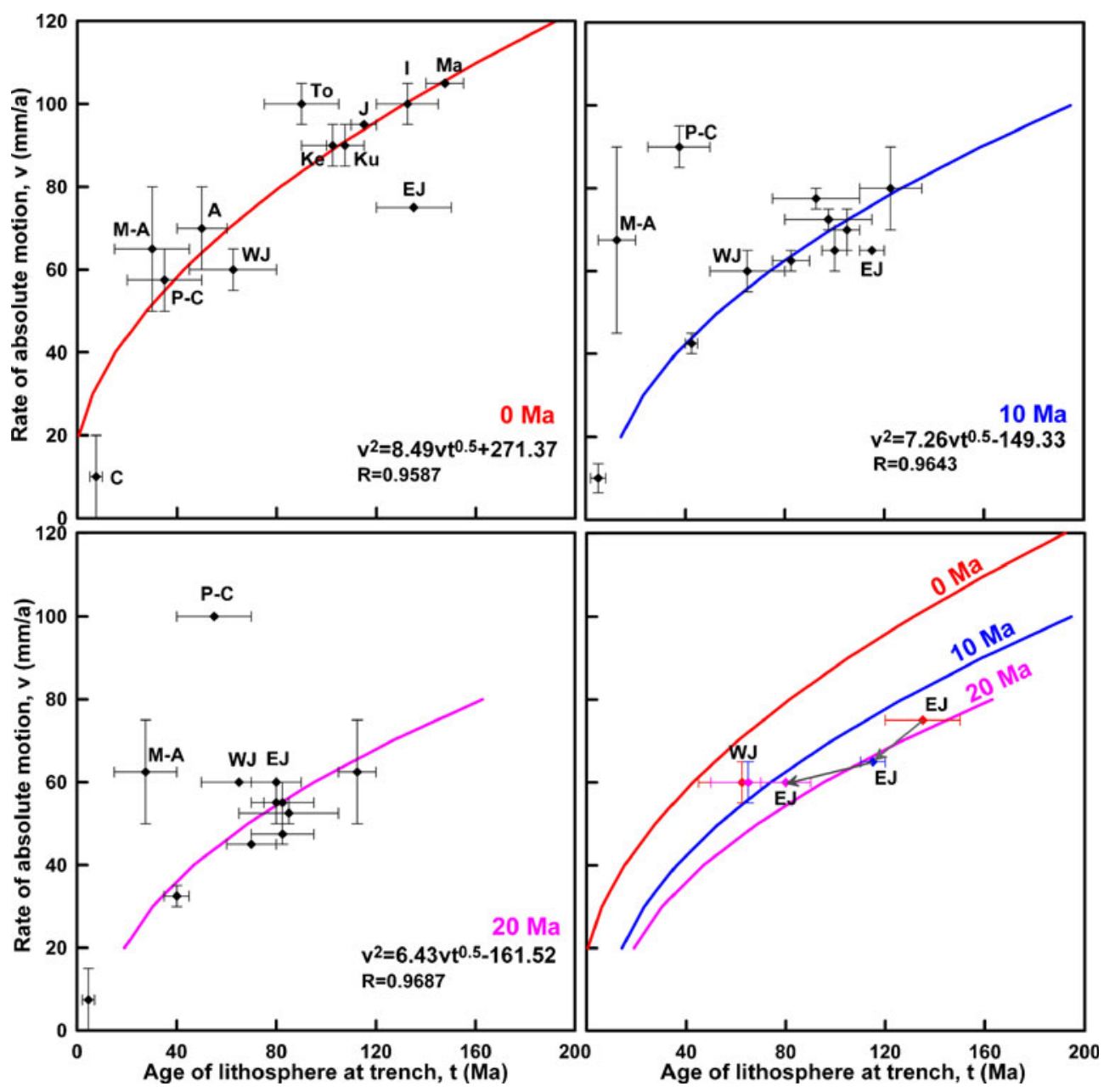

Figure 6. Rate of absolute plate motion (v) vs. age of lithosphere at the trench ( $\mathrm{t}$ ) is plotted in three different time windows at 0,10 and $20 \mathrm{Ma}$, respectively. The median rate of motion is plotted against the median age of the lithosphere at each of the 12 trenches. Bars indicate ranges in age and rate, and not errors. The nonlinear relationship is $v^{2}=a v t^{0.5}+b$, where $a$ and $b$ are the two constants (Carlson et al 1983). Data are taken from Sdrolias and Müller (2006), for constructing these models. The bottom right panel shows the position of East and West Java at 0, 10 and $20 \mathrm{Ma}$ (same as in other three panels). It may be noted that in between 20 and 10 Ma time window East Java fits with the nonlinear relationship but not with 0 and 10 Ma. Ma: Mariana; I: Izu-Bonin; J: Japan; Ke: Kermedec; Ku: Kuril; T: Tonga; P-C: Peru-Chile; M-A: Middle America; A: Aleutian; C: Cascadia; EJ: East Java; WJ: West Java.

view to explain the above discrepancy for both the Middle-America and Peru-Chile trench.

Regarding the timing of slab detachment process, we draw support from the variation of thermal parameter $(\Phi)$, along the strike of Indonesia. There is an abnormal increase in $\Phi$ from $4 \times 10^{3} \mathrm{~km}$, west of $105^{\circ} \mathrm{E}$ longitude to $5.6 \times 10^{3} \mathrm{~km}$ east of $105^{\circ} \mathrm{E}$ longitude (Kirby et al 1996). We calculated the thermal parameter at 10, 20,30, 40 and 50 Ma for East Java, West Java and Sumatra, respectively and plotted along the strike of the Sunda arc. It is generally considered that to produce deep focus earthquakes in a subduction zone, $\Phi$ should be greater than $5 \times 10^{3} \mathrm{~km}$ (Kirby et al 1996). It appears, that West Java started producing deep earthquakes right from $20 \mathrm{Ma}$, however, East Java from $30 \mathrm{Ma}$ (figure 7). Thus considering both nonlinear relationship and thermal parameter
$(\Phi)$ through different time windows, it can be proposed that the slab detachment beneath Java, took place about 10-20 Ma (Early Miocene to Late Miocene) (Keep and Haig 2010). However, plate reconstruction suggests that the Australian continental lithosphere started colliding about 9$10 \mathrm{Ma}$ ago (Keep and Haig 2010). Thus we suggest that slab detachment occurred well before the interaction of buoyant Australian continental mass and the slowdown in absolute plate motion is the consequence of the gradual slab detachment process.

\subsection{Nucleation of slab detachment}

With the available data and arguments, we can only propose a hypothesis on the evolution of slab detachment in the region. Interestingly slab tearing 


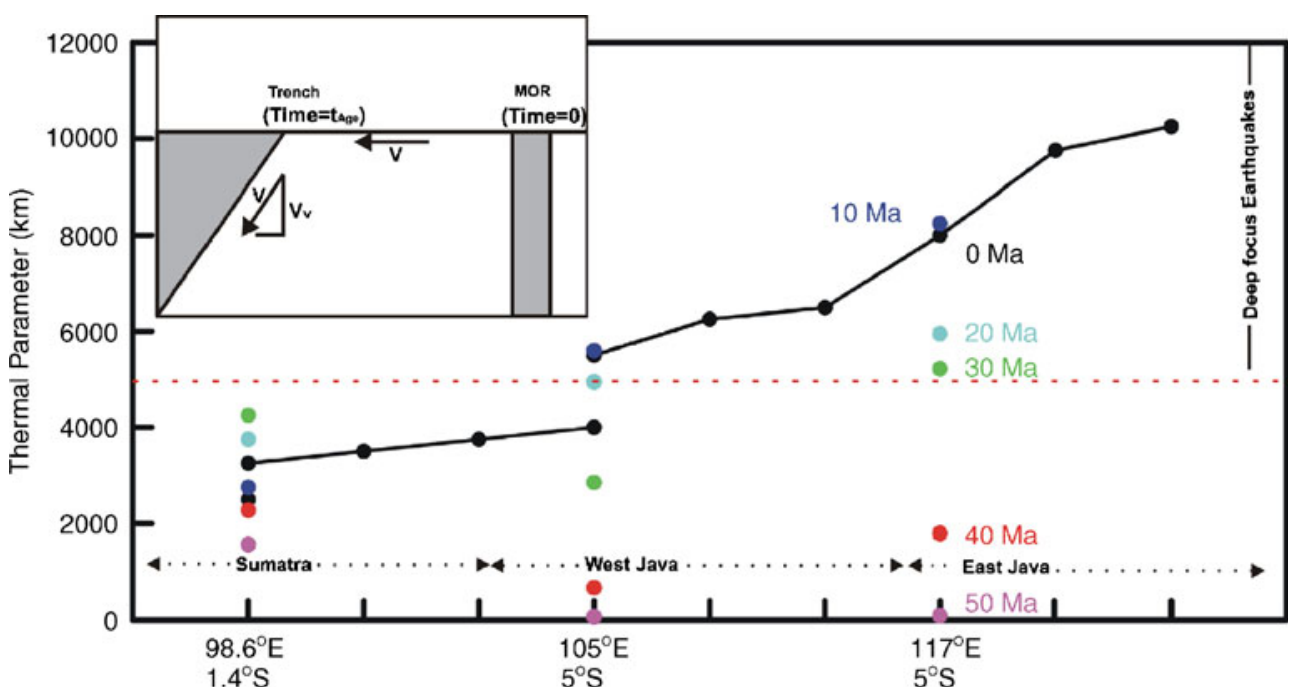

Figure 7. In the inset small panel represents the concept of thermal parameter. Thermal parameter $(\Phi)$ is defined as the product of vertical subduction velocities $\left(V_{V}\right)$ and the age of the lithosphere at the trench $\left(t_{\text {Age }}\right)$. Variation in $\Phi$ from 50 Ma to $0 \mathrm{Ma}$ along the strike of the trench is represented in the main panel. To estimate $\Phi$ for Sumatra, West Java and East Java regions, from $0 \mathrm{Ma}$ to $50 \mathrm{Ma}$ time intervals, data are taken from Sdrolias and Müller (2006), and plotted over the model proposed by Kirby et al (1996). To produce deep focus earthquakes in subduction zone, $\Phi$ should be $\geq 5 \times 10^{3} \mathrm{~km}$ ( $\mathrm{shown}$ by red dashed line). It is observed that West Java started producing deeper earthquakes from past 20 Ma and East Java from 30 Ma. However, Sumatra did not produce deeper earthquakes right from past 50 Ma to 0 Ma. MOR: Mid Oceanic Ridge.

has been reported globally where the plate boundary geometry dramatically changes like ends of arcs or where ridges are being subducted (Vogt 1973; Vogt et al 1976). It is also proposed that the arrival of trench parallel buoyancy variations in terms of aseismic ridges, seamounts, oceanic plateaus and continental fragments at subduction zones are likely to impede subduction rollback (Harris 1992), as a result it divides the subduction zone into segments with differential rollback velocities which trigger slab tearing (van der Hilst and Seno 1993; Levin et al 2002; Miller et al 2006; Rosenbaum et al 2008). It has been suggested that a small horizontal tear is sufficient to drive slab detachment along the strike of the slab (Yoshioka and Wortel 1995). But even now it is a highly debatable issue as to what nucleated the horizontal tear in the subducted Indo-Australian slab. It is possible that this detachment was initiated by the oceanic spreading centre at the western Sunda arc during the Early Tertiary. Change to oblique subduction, because of rotation of the Sumatra along with the interaction of relatively young buoyant lithosphere at the trench, may have jointly ceased subduction temporarily at shallow depths. While at deeper depth, the older slab continued to sink at greater depth. It probably resulted in a small horizontal tear in the subducted slab at the western end. The small horizontal tear propagated eastward because of the lateral migration of locus of maximum slab pull force concentration with time (Wortel and
Spakman 2000), which finally led to slab detachment of the subducted Indo-Australian slab.

\subsection{Average migration velocities of the tear}

The next issue is how fast was the lateral migration of the tear along the strike of the slab in the eastern Sunda arc. We roughly estimated the average migration velocity $V_{M}(\mathrm{~cm} / \mathrm{yr})$ (Yoshioka and Wortel 1995) by assuming

$$
V_{M} \sim \frac{L_{M}}{\left(D_{B}-D_{A}\right) / V_{B}}
$$

where $L_{M}(\mathrm{~km})$ is the length of the horizontal tear along the strike of the slab, $D_{A}$ and $D_{B}(\mathrm{~km})$ are the depths of the slab just above and below the tear, respectively, and $V_{B}(\mathrm{~cm} / \mathrm{yr})$ is the falling velocity of the detached slab. We may roughly estimate the possible range of $V_{B}$, however, $L_{M}, D_{A}$ and $D_{B}$ can be estimated from the shape of the seismic gap or from the results of tomographic study. If detachment occurred after the subduction of the oceanic plate, in order to make a horizontal tear within the downgoing slab, $V_{B}$ must be faster than the convergence rate. In order to explore the dynamic interaction between the broken slab fragments of subducting lithosphere and the surrounding viscous mantle, we evaluate the deformation pattern of a rectangular block sinking into the mantle by means of two-dimensional numerical model within dynamically deforming interface. We 
have used a thermo-mechanical code called I2VIS, which employed finite-difference method over a half-staggered grid (Gerya and Yuen 2003). Free slip is assumed on all surrounding boundaries. We assume that the broken slab falling is controlled only by the buoyancy forces arising from the density contrast and by the viscosity ratio between the broken slab fragments and the surrounding viscous fluid. All viscosities are Newtonian and uniform within the slab and the mantle. However, more complex rheology may prevail in nature, especially, the one that account for the influences of the temperature dependent viscosity (Billen and Gurnis 2005), but we keep our model as simple as possible in order to quantify its behaviour as the function of effective broken slab fragment to mantle viscosity ratio which we vary from 0.001 to 1000 . We neglect the viscous stratification between lower and upper mantles, as the detached Java slab fragment does not extend up to the lower mantle (figure 2). Using the simple two-dimensional numerical model, we estimated $V_{B}$ as $1.6-2.39 \mathrm{~cm} / \mathrm{yr}$. Further, using $L_{M}=1000 \mathrm{~km}, D_{A}=400 \mathrm{~km}, D_{B}=700 \mathrm{~km}$ and $V_{B}=1.6-2.39 \mathrm{~cm} / \mathrm{yr}$ in the above equation, we obtained average migration velocity, $V_{M}$, as $5.33-7.96 \mathrm{~cm} / \mathrm{yr}$. Thus the sinking velocity of the detached slab segment are higher than sinking velocity for the non-detached slab fragments, which further supports our argument of slab detachment.

\section{Conclusion}

A wedge-shaped seismic gap both along the strike of the slab (from $105^{\circ} \mathrm{E}$ to $116^{\circ} \mathrm{E}$ ) and in-depth profile (300-500 km), tomographic study, and most importantly geochemically distinct type of arc magmatic rocks, are some of the convincing evidences about the slab detachment process beneath the eastern Sunda arc. Spatial distribution of arc volcanoes and their abnormal geochemical character can only be explained in a steady-state subduction scenario, if we accept slab detachment process. Probably that is the reason for the development of overlapping end of two volcanic lines in this region. We propose that those arc volcanoes are the guiding compass to identify the lateral extent of slab detachment on subducted slab. Interaction of spreading centre with Sunda arc in Early Tertiary period probably nucleated small horizontal tear on the slab and slab detachment process dominated beneath East Java arc after 20 Ma (Early Miocene) but before $10 \mathrm{Ma}$ (Late Miocene), well before the collision of Australian continental mass. We suggest that interaction of such buoyant spreading centre temporarily slowed down the rate of convergence, causing a more effective stress concentration, which was sufficient to drive lateral propagation of the horizontal tear in the east direction. Such physical lithospheric gap affects the seismicity, causing seismic gap, slowdown in subduction velocity because of the sudden loss of slab pull force, enhances asthenospheric inflow along the lateral edges of the tear, and results in geochemically distinct type of highly mafic magmatic activities in this region.

However, we need a detailed geochemical investigation of these active volcanoes and tomographic imaging that may help us to locate exact limit and position of the horizontal tear on subducted Indo-Australian slab beneath Sunda arc. Apart from that, detailed mapping of elevated coral terraces in the Java Island and its accurate age dating may also provide important clue regarding the rate of uplift, which may also correlate with slab detachment process (Mitchell and Warden 1971).

\section{Acknowledgements}

The authors thank the Council of Scientific and Industrial Research and Ministry of Earth Sciences, New Delhi for financial support.

\section{References}

Barazangi M, Isacks B L, Oliver J, Dubois J and Pascal G 1973 Descent of lithosphere New Hebrides, Tonga-Fiji and New Zealand: Evidence for detached slabs; Nature 242 98-101.

Bautista B C, Bautista M L P, Oike K, Wu F T and Punongbayan R S 2001 A new insight on the geometry of subducting slabs in northern Luzon, Philippines; Tectonophys. 339(3-4) 279-310.

Billen M I and Gurnis M 2005 Constraints on subducting plate strength within the Kermadec trench; J. Geophys. Res. 110 B05407.

Carlson R L, Hilde T W C and Uyeda S 1983 The driving mechanism of Plate tectonics: Relation to age of the lithosphere at trench; Geophys. Res. Lett. 10 297-300.

Curray J R 2005 Tectonics and history of the Andaman Sea region; J. Asian Earth Sci. 25 187-232.

Davies J H and Stevenson D J 1992 Physical model of source region of subduction zone volcanics; J. Geophys. Res. 97 2037-2070.

Engdahl E R, Hilst R V D and Buland R 1998 Global teleseismic earthquake relocation with improved travel time and procedures for depth determination; Bull. Seismol. Soc. Am. 88 722-743.

Ferrari L 2004 Slab detachment control on mafic volcanic pulse and mantle heterogeneity in central Mexico; Geology 32 77-80.

Fitch T J 1972 Plate convergence, transcurrent faults and internal deformation adjacent to Southeast Asia and the western Pacific; J. Geophys. Res. 77 4432-4460.

Foden J D and Varne R 1980 The Petrology and tectonic setting of Quaternary-Recent volcanic centres of Lombok and Sumbawa, Sunda arc; Chem. Geol. 30 201-226.

Gerya T V and Yuen D A 2003 Characteristics-based marker-in-cell method with conservative finite-differences 
schemes for modeling geological flows with strongly variable transport properties; Phys. Earth Planet. Inter. 140 $293-318$.

Grove T L, Till C B, Lev E, Chatterjee N and Medard E 2009 Kinematic variables and water transport control the formation of arc volcanoes; Nature 459 694-697.

Guivel C et al 2006 Miocene to Late Quaternary Patagonian basalts $\left(46-47^{\circ} \mathrm{S}\right)$ : Geochronometric and geochemical evidence for slab tearing due to active spreading ridge subduction; J. Volcanol. Geotherm. Res. 149 346-370, doi: 10.1016/j.jvolgeores.2005.09.002.

Gvirtzman Z and Nur A 1999 Plate detachment, asthenosphere upwelling, and tomography across subduction zones; Geology 27(6) 563-566.

Hall R 1997 Cenozoic plate tectonic reconstructions of SE Asia, Petroleum Geology of Southeast Asia; Geol. Soc. London, Spec. Publ. 126 11-23.

Harris R A 1992 Peri-collisional extension and the formation of Oman-type ophiolites in the Banda Arc and Brooks Range; In: Ophiolites and their modern oceanic analogues (eds) Parson L M, Murton B J and Browning P, Geol. Soc. London, Spec. Publ. 60 301-325.

Hofman A W 1997 Mantle geochemistry: The message from oceanic volcanism; Nature 385 219-229.

Isacks B and Molnar P 1971 Distribution of stresses in the descending lithosphere from a global survey of focal mechanism solutions of mantle earthquakes; Rev. Geophys. Space. Phys. 9 103-174.

Keep M and Haig D W 2010 Deformation and exhumation in Timor: Distinct stages of a young orogeny; Tectonophys. 483 93-111.

Kincaid C and Olson P 1987 An experimental study of subduction and slab migration; J. Geophys. Res. 92 $13,832-13,840$.

Kincaid C and Griffiths R W 2003 Laboratory models of the thermal evolution of the mantle during rollback subduction; Nature 425 58-62, doi: 10.1038/nature01923.

Kirby S H, Stein S, Okal E A and Rubie D C 1996 Metastable mantle phase transformations and deep earthquakes in subducting oceanic lithosphere; Rev. Geophys. 34 261-306.

Koper K D, Weins D A, Dorman L M, Hildebrand J A and Webb S C 1999 Constraints on the origin of slab and wedge anomalies in Tonga from the ratio of $\mathrm{S}$ to $\mathrm{P}$ anomalies; J. Geophys. Res. 104 15,089-15,104.

Kopp H, Flueh E R, Petersen C J, Weinrebe W and Wittwer A 2006 The Java margin revisited: Evidence for subduction erosion off Java; Earth Planet. Sci. Lett. 242 130-142.

Kundu B and Gahalaut V K 2010 An Investigation into the seismic potential of the Irawaddy region, Northern Sunda arc; Bull. Seismol. Soc. Am. 100 891-895.

Levin V, Shapiro N, Park J and Ritzwoller M 2002 Seismic evidence for catastrophic slab loss beneath Kamachatka; Nature 418 763-767.

Lister G, Kennett B, Richards S and Forster M 2008 Boudinage of a stretching slablet implicated in earthquakes beneath the Hindu Kush; Nature Geosci. 1 196-201.

Luhr J F and Haldar D 2006 Barren Island Volcano (NE Indian Ocean): Island-arc high-alumina basalts produced by troctolite contamination; J. Volcanol. Geochem. Res. 149 177-217.

Maury RC et al 2000 Post-collisional Neogene magmatism of the Mediterranean Maghreb margin: A consequence of slab breakoff; C. R. Acad. Sci., Ser. IIa 331 159-173.

McCaffrey R 1992 Oblique plate convergence, slip vectors, and forearc deformation; J. Geophys. Res. 97 8905-8915.
McCulloch M T and Gamble J A 1991 Geochemical and geodynamical constraints on subduction zone magmatism; Earth Planet. Sci. Lett. 102 358-374.

Michael A J 1987 Use of focal mechanisms to determine stress: A control study; J. Geophys. Res. 92 357-368.

Miller M S, Gorbatov A and Kennet B L N 2006 Threedimensional visualization of a near-vertical slab tear beneath the southern Mariana arc; Geochem. Geophys. Geosyst. 7(6) Q06012, doi: 10.1029/2005GC001110.

Mitchell A H G and Warden A J 1971 Geological evolution of New Hebrides island arc; J. Geol. Soc. London 127 501-529.

Müller C et al 2008 From subduction to collision: The Sunda-Banda Arc Transition; EOS, Transaction, American Geophysical Union 89 No. 6.

Nicholls I A and Whitford D J 1983 Potassium-rich volcanic rocks of the Muriah Complex, Java, Indonesia: Products of multiple magma sources?; J. Volcanol. Geochem. Res. 18 337-359.

Obayashi M, Yoshimitsu J and Fukao Y 2009 Tearing of stagnant slab; Science 234 1173-1175.

Pesicek J D, Thurber C H, Widiyantoro S, Engdahl E R and DeShon R H 2008 Complex slab subduction beneath northern Sumatra, Geophys. Res. Lett. 35 L20303, doi: 10.1029/2008GL0352662.

Protti M, Gundel F and McNally K 1994 The geometry of the Wadati-Benioff zone under southern Central America and its tectonic significance: Results from a high-resolution local seismographic network; Phys. Earth Planet. Inter. $84271-287$.

Richards S, Lister G and Kennett B 2007 A slab in depth: Three-dimensional geometry and evolution of the Indo-Australian plate, Geochem. Geophys. Geosyst. 12 Q12003, doi: 10.1029/2007GC001657.

Rosenbaum G, Gasparon M, Lucente F P and Peccerillo A 2008 Kinematics of slab tear faults during subduction segmentation and implications for Italian magmatism; Tectonics 27 TC2008, doi: 10.1029/2007TC002143.

Schellart W P 2004 Quantifying the net slab pull force as a driving mechanism for plate tectonics; Geophys. Res. Lett. 31 L07611, doi: 10.1029/2004GL019528.

Schellart W P 2008 Kinematics and flow patterns in deep mantle and upper mantle subduction models: Influence of the mantle depth and slab to mantle viscosity ratio; Geochem. Geophys. Geosyst. 9 Q03014, doi: 10.1029/2007GC001656.

Schellart W P, Freeman J, Stegman D R and Mories L 2007 Evolution and diversity of subduction zones controlled by slab width; Nature 446 308-311.

Schellart W P, Kennett B L N, Spakman W and Amaru M 2009 Plate reconstructions and tomography reveal a fossil lower mantle slab below the Tasman Sea; Earth Planet. Sci. Lett. 278 143-151.

Schellart W P, Stegman D R, Farrington R J, Freeman J and Moresi L 2010 Cenozoic tectonics of western North America controlled by evolving width of Farallon slab; Science 329 316-319, doi: 10.1126/science.1190366.

Sdrolias M and Müller R D 2006 Controls on back-arc basin formation; Geochem. Geophys. Geosyst. 7(4) Q04016, doi: 10.1029/2005GC001090.

Stegman D R, Freeman J, Schellart W P, Moresi L and May D 2006 Influence of trench width on subduction hinge retreat rates in $3-\mathrm{D}$ models of slab rollback; Geochem. Geophys. Geosyst. 7(3) Q03012, doi: 10.1029/2005GC001056.

Syracuse E M and Abers G A 2006 Global compilation of variations in slab depth beneath arc volcanoes and implications; Geochem. Geophys. Geosyst. 7 Q05017, doi: 10.1029/2005GC001045. 
Tatsumi Y 2005 The subduction factory: How it operates in the evolving Earth; GSA Today 15 4-10.

van der Hilst R D and Seno T 1993 Effects of relative plate motion on the deep structure and penetration depth of slabs below the Izu-Bonin and Mariana island arcs; Earth Planet. Sci. Lett. 120 395-407.

Vogt P R 1973 Subduction and aseismic ridges; Nature 241 $189-191$.

Vogt P R, Lowrie A, Bracey D R and Hey R N 1976 Subduction of aseismic oceanic ridges: Effects on shape, seismicity, and other characteristics of consuming plate boundaries; Spec. Pap. Geol. Soc. Am. 17259 pp.

Whitford D J, Nicholls I A and Taylor S R 1979 Spatial variations in the geochemistry of Quaternary lavas across the Sunda Arc in Java and Bali; Contrib. Mineral. Petrol. 70 341-356.

Widiyantoro S and van der Hilst 1996 Structural and evolution of lithospheric slab beneath the Sunda arc, Indonesia; Science 271 1566-1570.

Wortel M J R and Spakman W 2000 Subduction and slab detachment in the Mediterranean-Carpathian region; Science 290 1910-1917.

Yogodzinski G M et al 2001 Geochemical evidence for the melting of subducting oceanic lithosphere at plate edges; Nature 409 500-504.

Yoshioka S and Wortel M J R 1995 Three-dimensional numerical modelling of detachment of subducted lithosphere; J. Geophys. Res. 100 22,223-22,244. 